\title{
CZTERY OBIEKTY REPREZENTUJĄCE DWA KIERUNKI SPOJRZENIE NAARCHITEKTURĘ POLSKĄ XXI WIEKU
}

\author{
Hubert Trammer \\ Katedra Architektury Urbanistyki i Planowania Przestrzennego, Wydział \\ Budownictwa i Architektury, Politechnika Lubelska \\ Chair of Architecture, Urban Design and Spatial Planning Faculty of Civil \\ Engineering and Architekture, Lublin University of Technology \\ e-mail: huberttrammer@wp.pl,h.trammer@pollub.pl
}

\begin{abstract}
Streszczenie. W niniejszej publikacji cztery dzieła architektury powstałe w Polsce w XXI wieku zostały zestawione parami w dwa kierunki w architekturze dobrane pod kątem zbiorów łączących je cech. Główny temat publikacji uzupełniają wstępne rozważania na temat możliwych pól analizy architektury powstającej w Polsce w XXI wieku.
\end{abstract}

Słowa kluczowe: architektura polska, architektura XXI wieku, architektura współczesna, Filharmonia Szczecińska, Cricoteka, Gdański Teatr Szekspirowski, Klasztor Franciszkanów w Tychach, Estudio Barozzi Veiga, Renato Rizzi, Stanisław Niemczyk

W maju 2015 roku, oddany do użytku w poprzednim roku, gmach Filharmonii Szczecińskiej im. Mieczysława Karłowicza został uhonorowany Nagrodą Unii Europejskiej im. Miesa van der Rohe dla współczesnej architektury. To prestiżowe wyróżnienie można uznać za dowód dobrej kondycji architektury w Polsce, a także za podkreślenie kilku mających w niej miejsce w początkach XXI wieku zjawisk. Po pierwsze powstawania w dużej ilości obiektów kultury. Po drugie dużego znaczenia środków finansowych Unii Europejskiej dla powstających w Polsce inwestycji. Po trzecie dużego wzrostu zainteresowania architekturą w Polsce, a także wzrostu zainteresowania polską architekturą za granicą. Po czwarte zwiększenia liczby obiektów realizowanych w wyniku konkursów architektonicznych - przy tym jest to wzrost wynikający przede wszystkim ze wzrostu ilości nowych inwestycji, a w mniejszym stopniu z poprawy proporcji obiektów wznoszonych w konsekwencji konkursów do budowanych przez architektów uzyskujących zlecenie w inny sposób. Wreszcie, po piąte, za podkreślenie większego niż w poprzednich dziesięcioleciach otwarcia Polski na działalność architektów z innych krajów. Otwarcie mającego w Polsce wielowiekową tradycję. Zjawisk charakterystycznych dla polskiej architektury początku XXI wieku jest naturalnie więcej. Przy tym zjawiska wymienione wyżej, które można określić jako dotyczące zewnętrznego wymiaru architektury nie mają bezpośredniego związku ze sposobami kształtowania poszczególnych dzieł architektury.

Duża ilość powstającej obecnie w Polsce interesującej architektury stanowi dobry pretekst do różnego rodzaju rozważań. Można na wiele sposobów analizować jej jakość. Warto także zastanawiać się także nad tym na ile nowe inwestycje świadczą o rozwoju, a na ile są sztucznie kreowanymi jego symbolami, w rzeczywistości zaś przez generowane przez nie koszty utrzymania mogą przyczynić się do powstania kryzysu. Ważna kwestią jest refleksja nad tym jakie inwestycje powstają w bardzo dużych ilościach, a jakie w ilościach śladowych, a także tym jakie dziedziny ulegają wręcz regresowi. Polska w szybkim tempie nadrabia zaległości w budowie obiektów kultury, urządzaniu przestrzeni publicznych w mniejszych i większych miejscowościach, czy remontach i rozbudowie infrastruktury komunikacyjnej. Inwestycje w tym ostatnim zakresie mogą budzić wątpliwość czy nie są prowadzone ponad stan. Argumentem na rzecz tej tezy może być zestawienie faktu, iż łączna długość autostrad i dróg ekspresowych w Polsce wzrosła w latach 2003-2015 z 631 do 3391 kilometrów, z tym iż, dużo 
bogatsza od Polski, Wielka Brytania posiada 3674 kilometry takich dróg, a w najbliższych latach ich długość w Polsce ma ulec podwojeniu. Jednocześnie zamykane jest wiele lokalnych szkół, czy ograniczana komunikacja publiczna na terenach położonych poza największymi metropoliami i głównymi szlakami drogowymi i kolejowymi. Dużym problemem jest regres w budownictwie mieszkaniowym, zwłaszcza przeznaczonym dla ludzi mniej zamożnych. Pomimo dużych potrzeb liczba mieszkań powstających rocznie wciąż jest wyraźnie mniejsza niż za czasów ustroju komunistycznego. Rozważać można, zwłaszcza w kontekście dużej ilości powstających w Polsce dzieł architektów z zagranicy, także to na ile mamy do czynienia z polską architekturą, a na ile z powstającą na terenie Polski architekturą globalną.

Oprócz zaznaczonych powyżej ważnych kwestii społecznych, politycznych, ekonomicznych i kulturowych związanych z architekturą interesującym polem analiz mogą być kwestie, które można określić jako wewnątrz architektoniczne, czyli dotyczące kształtu architektury jako takiej. Architektura powstająca w Polsce od początku XXI wieku stanowi dobry materiał na szereg poświęconych temu tematowi obszernych, przekrojowych monografii. Niniejszy artykuł stanowi niewielki przyczynek do takich rozważań. Tematem są kierunki w architekturze. Punktem wyjścia do rozważań gmach Filharmonii Szczecińskiej im. Mieczysława Karłowicza i analiza wybranych zastosowanych w nim rozwiązań mogących być uznane za cechy określonego kierunku w architekturze. Dalej pokazany zostanie kolejny przykład, który można zaliczyć do kierunku wyznaczonego w oparciu o analizę gmachu Filharmonii Szczecińskiej, a następnie kolejne dwa przykłady, które można uznać za przykłady innego kierunku. Także określonego w oparciu o cechy jakie te przykłady posiadają. Tak więc artykuł ten stanowi opracowanie mocno fragmentaryczne i wycinkowe.

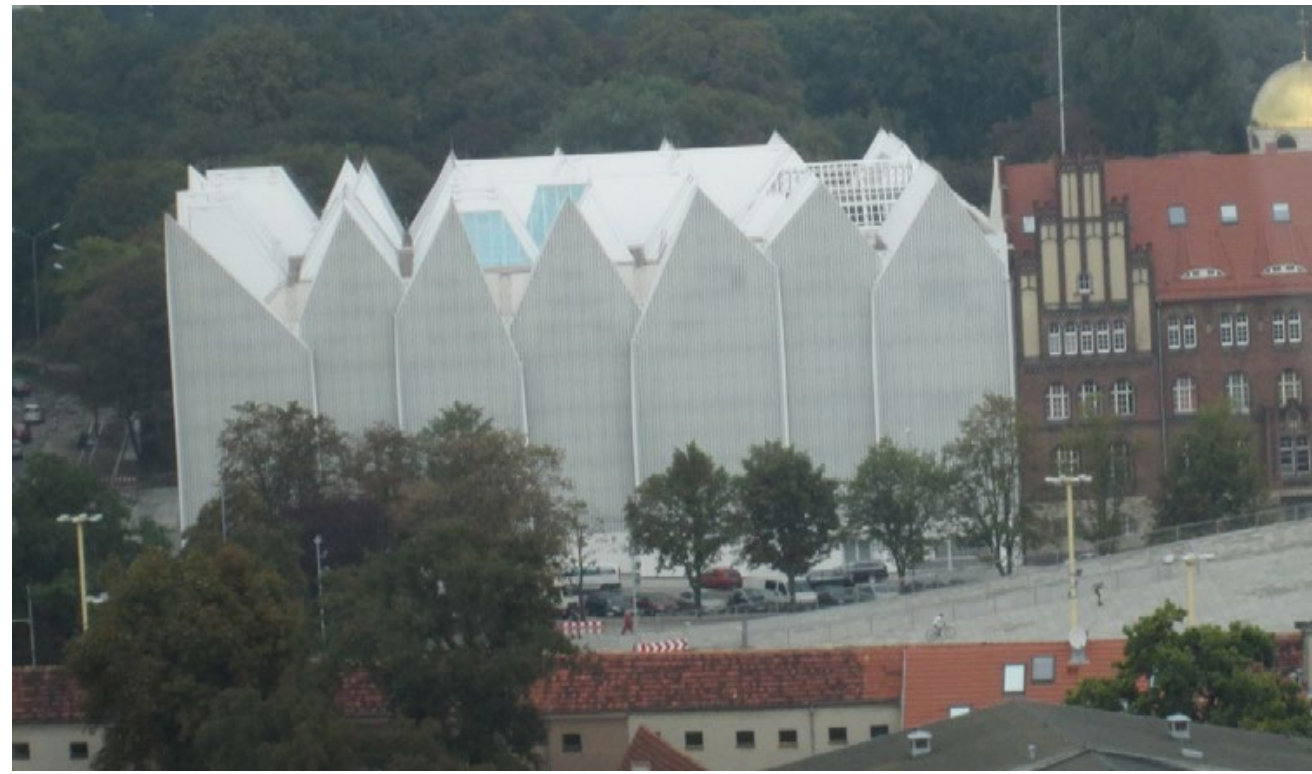

Ryc. 1. Gmach Filharmonii Szczecińskiej im. Mieczysława Karłowicza. Widok z wieży katedry. Z prawej strony widoczny fragment budynku komendy policji. Źródło: fot. H. Trammer, 21 września 2014 r. Fig. 1. Szczecin Philharmonic. View from the tower of the cathedral church. On the right hand side part of the police headquarters buidling. Source: phot. Hubert Trammer, September 21st, 2014

Powstanie gmachu Filharmonii Szczecińskiej jest konsekwencją wygrania konkursu architektonicznego przez działającą w Barcelonie pracownię Estudio Barozzi Veiga, którą prowadzą architekci Fabrizio Barozzi (Włoch) i Alberto Veiga (Hiszpan), ale pracują w niej architekci z różnych krajów. W tym, uczestnicząca w projekcie Filharmonii Szczecińskiej 
od samego początku (od znalezienia informacji o konkursie) Polka - Agnieszka Samsel. Na etapie projektów pokonkursowych i budowy w pracy nad powstaniem obiektu filharmonii pracowali także architekci ze szczecińskiej pracowni Studio A4.

Patrząc na sposób kształtowania architektury gmachu Filharmonii Szczecińskiej (Ryc. 1-2), wśród charakterystycznych cech można wyróżnić:

- ekspresyjną i łatwo zapamiętywalną formę zewnętrzną, dającą się przedstawić w sposób dający wrażenie całości, za pomocą jednej fotografii

- inspirację formami z przeszłości nie związanymi bezpośrednio z miejscem w którym obiekt się znajduje

- dialog formalny nowej architekturą z sąsiadującą z nią starą zabudową oparty na tworzeniu czytelnych relacji, jednakże bez powielania form starej architektury

- ujednolicenie wyrazu fasad za pomocą konsekwentnie przyjętego sposobu wykończenia sprawiającego iż wykończenie fasad przypomina opakowanie budynku, są one konsekwentnie ukształtowane jako powłoki obejmująca całość poprzez ich jednolite wykończenie elewacji w sposób zapewniający przepuszczanie światła, ale zacierający podział elewacji na części przezierne i nieprzezierne

- ukształtowanie bryły nowej architektury w sposób zwarty

- wykończenie powierzchni obiektu lekkimi materiałami wykończeniowymi nie odrywającymi roli konstrukcyjnej

- zastosowanie konstrukcji szkieletowej i ukrycie jej wewnątrz obiektu tak, iż nie wpływa ona zewnętrzny wyraz jego architektury

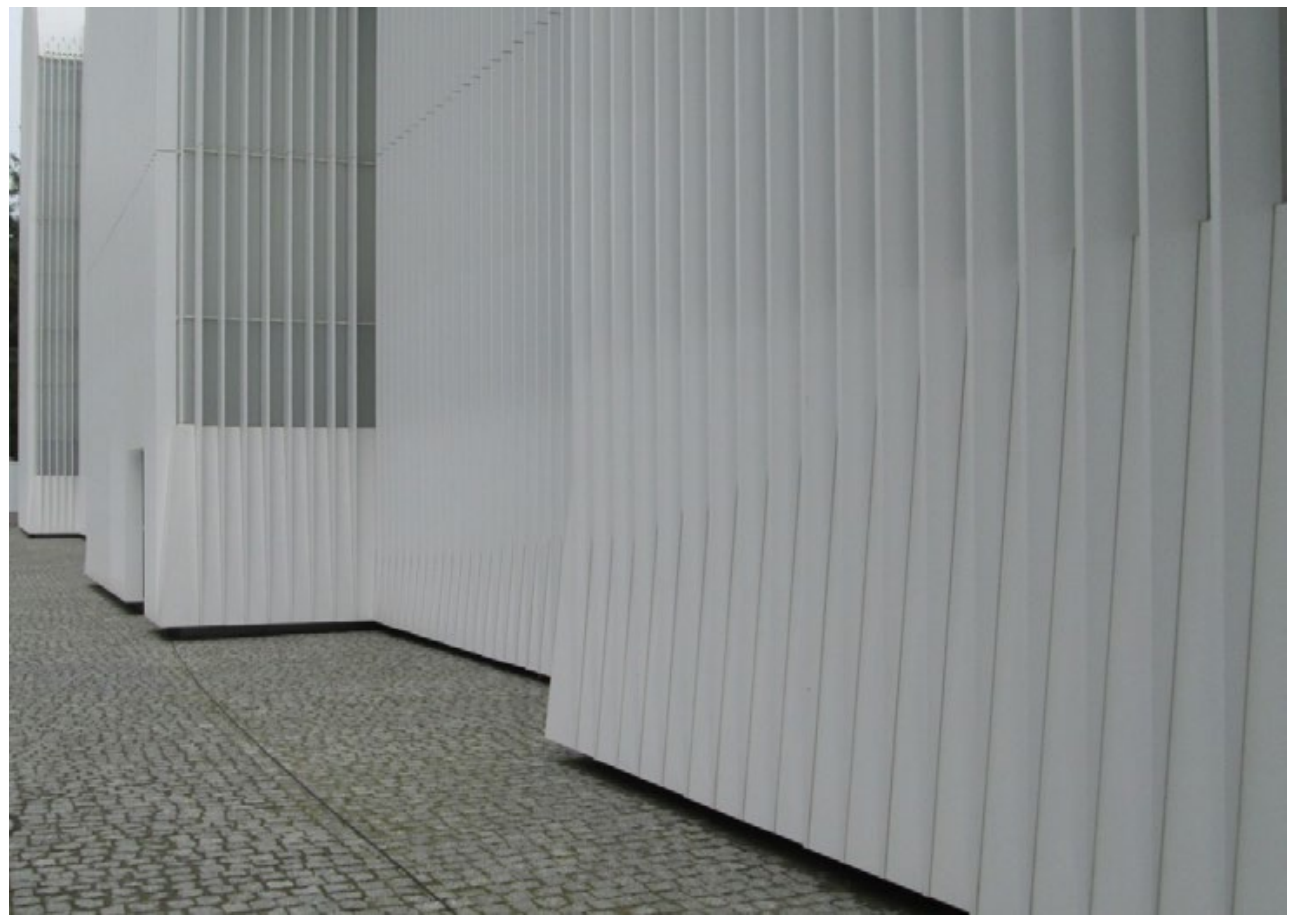

Ryc. 2. Gmach Filharmonii Szczecińskiej im. Mieczysława Karłowicza. Fragment elewacji. Źródło: fot. H. Trammer, 21 września 2014 r.

Fig. 2. Szczecin Philharmonic. Part of the facede. Source: phot. Hubert Trammer, September $21^{\text {st }}, 2014$

Te same cechy posiada nowo wzniesiona część siedziby Muzeum Tadeusza Kantora i Ośrodka Dokumentacji Sztuki Tadeusza Kantora Cricoteka w Krakowie (Ryc. 3-4.). W przypadku Filharmonii Szczecińskiej formami z przeszłości stanowiącymi źródło inspiracji była 
zabudowa typowa dla miast hanzeatyckich, zaś w przypadku Cricoteki rysunek Tadeusza Kantora Człowiek niosący na plecach stół.

Cricoteka jest dziełem wyłącznie polskich twórców - konsorcjum pracowni nsMoon Studio - architekci Sławomir Zieliński, Piotr Nawara i Agnieszka Szultk i Wizja - architekt Stanisław Deńko, oraz współpracujących z nimi innych architektów, konstruktorów Czesława Hodurka i Andrzeja Sobonia, a także innych specjalistów. Koncepcja tych autorów, będąca podstawą zlecenia im dalszych opracowań i prac nad realizacją obiektu, a także podstawą finalnego kształtu obiektu została wybrana w konkursie, w którym uczestniczyli architekci $\mathrm{z}$ różnych krajów.

Zespół wymienionych wyżej cech nadaje obu obiektom wyrazisty charakter i sprawia, iż pomimo braku bezpośredniego podobieństwa wizualnego można je uznać za należące do jednego kierunku w architekturze. Są też inne obiekty, które w mniejszym lub większym stopniu się w ten kierunek wpisują.

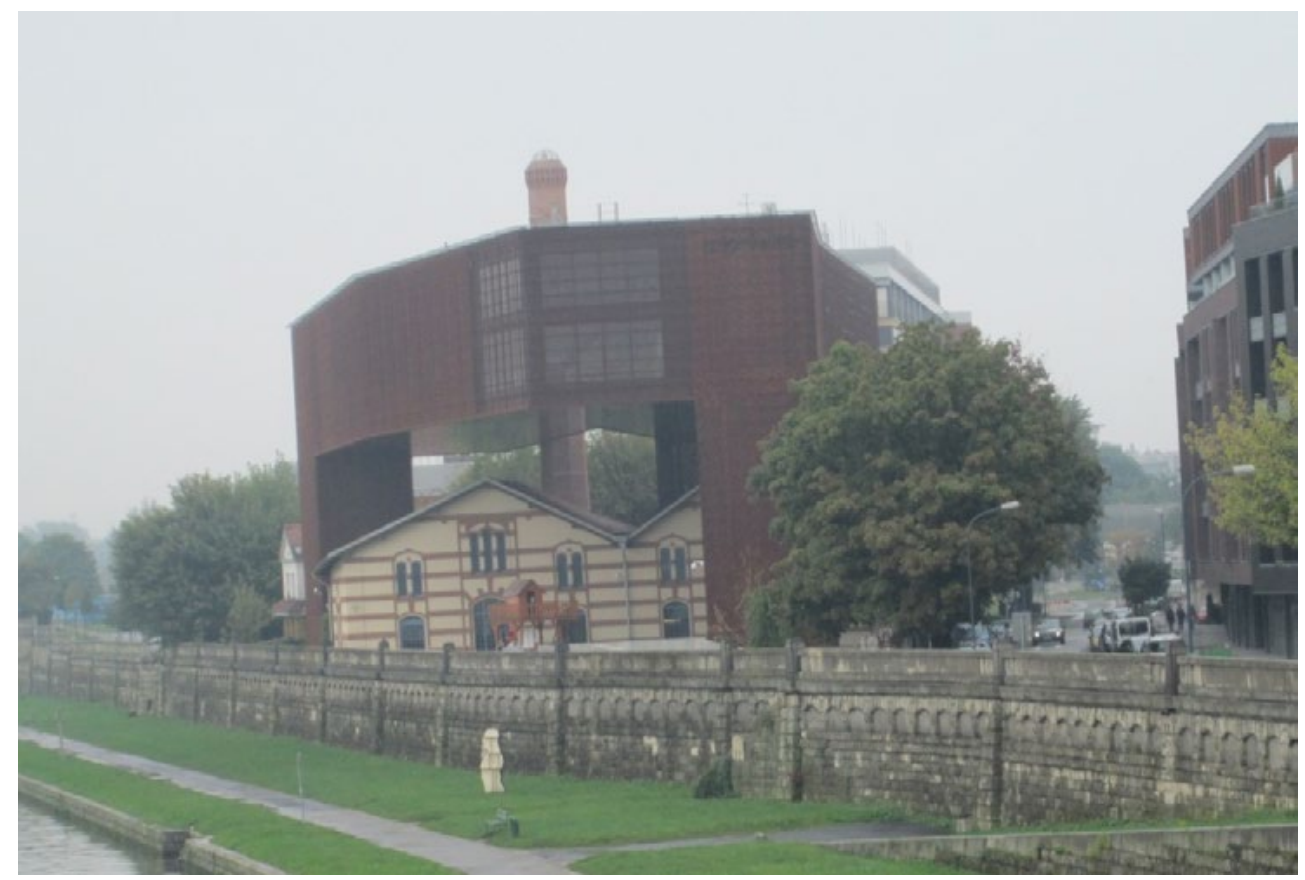

Ryc. 3. Siedziba Muzeum Tadeusza Kantora i Ośrodka Dokumentacji Sztuki

Tadeusza Kantora Cricoteka w Krakowie. Wiodczna relacja nowej części z dawnym budynkiem elektrowni. Źródło: fot. H. Trammer, 20 września 2014 r.

Fig. 3. Seat of the Tadeusz Kantor Museum and the Centre for the Documentation of the Art of Tadeusz Kantor Cricoteca in Cracow. One can trace the relation between the new part and the old building of the formr power station. Source: phot. Hubert Trammer, September $20^{\text {th }}, 2014$ 


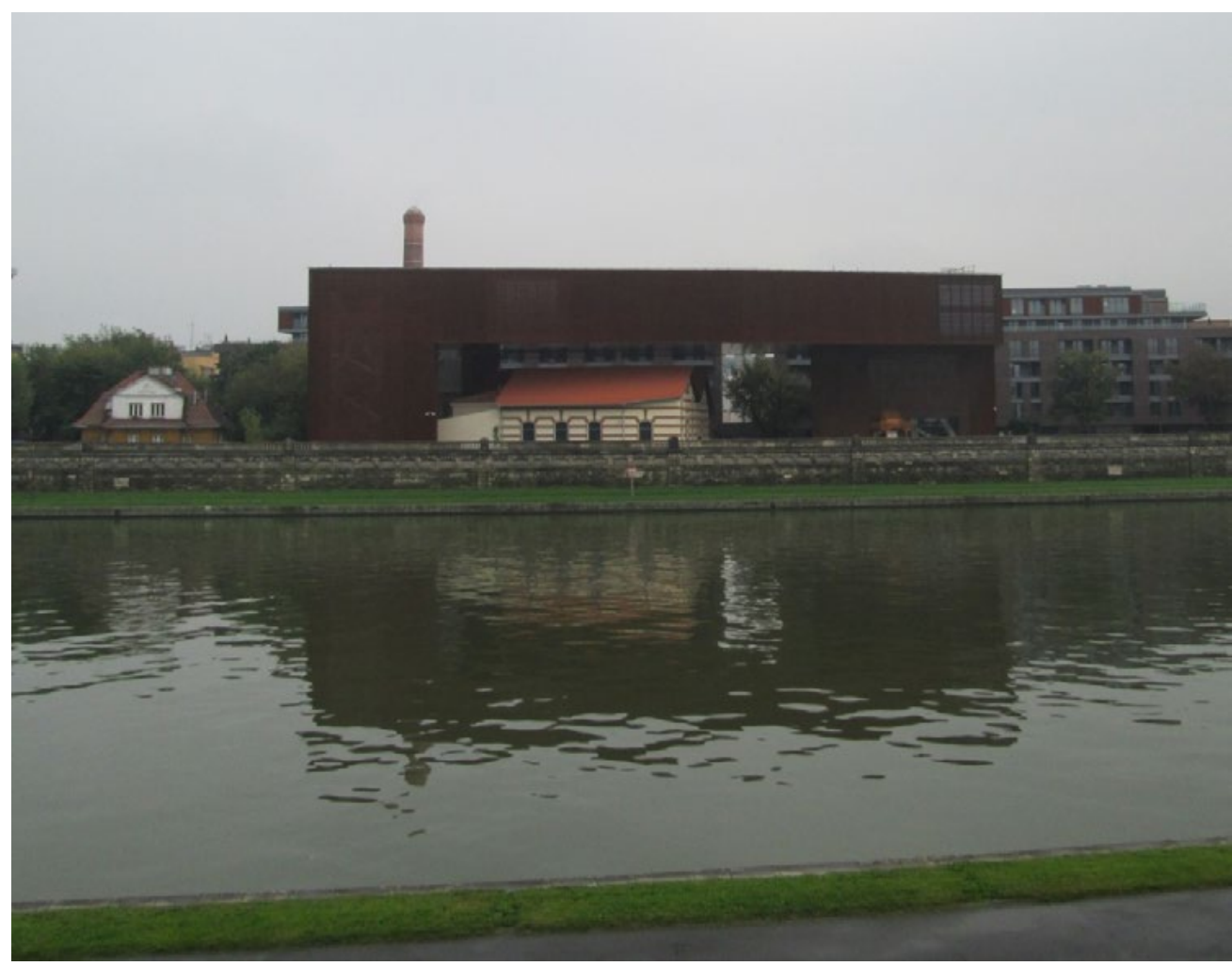

Ryc. 4. Siedziba Muzeum Tadeusza Kantora i Ośrodka Dokumentacji Sztuki Tadeusza Kantora Cricoteka w Krakowie. Widok z drugiej strony Wisły. Źródło: fot. H. Trammer, 20 września 2014 r.

Fig. 4. Seat of the Tadeusz Kantor Museum and the Centre for the Documentation of the Art of Tadeusz Kantor Cricoteca in Cracow. View form the other side of the

Vistula River. Source: phot. Hubert Trammer, September $20^{\text {th }}, 2014$

Kolejnym przykładem pary obiektów, które można uznać za reprezentujące wspólny kierunek w architekturze są Gdański Teatr Szekspirowski (Ryc. 5-9)oddany do użytku, tak samo jak Filharmonia Szczecińska, w 2014, oraz Klasztor Franciszkanów w Tychach (Ryc. 10-12), powstający od 2000 roku i wciąż będący w budowie. Architektem Gdańskiego Teatru Szekspirowskiego jest pracujący w Wenecji Renato Rizzi, który pracował nad projektem i realizacją wspólnie z włoską grupą projektową A.T.I., oraz pracownią Q-ARCH z Krakowa. Projekt Renato Rizziego został wybrany w międzynarodowym konkursie rozstrzygniętym w 2008 roku.

Architektem Klasztoru Franciszkanów w Tychach jest Stanisław Niemczyk, mieszkający i prowadzący swą pracownię w odległości kilkuset metrów od klasztoru. Franciszkanie zwrócili się do Stanisława Niemczyka bezpośrednio, zaś podstawowym kryterium wyboru była dla nich bliskość jego miejsca zamieszkania. Niemczyk na budowie jest niemal codzienne, jak sam mawia, nie składa wizyt na budowie, lecz jest tam stale.

Tak więc pod względem relacji architekta z miejscem budowy mamy między tymi dwoma obiektami istotną różnicę. Renato Rizzi jako architekt Gdańskiego Teatru Szekspirowskiego stanowi przykład relacji, jeśli nie globalnych to co najmniej, kontynentalnych. Stanisław Niemczyk, jako architekt Klasztoru Franciszkanów w Tychach, stanowi przykład relacji lokalnych.

Jednocześnie jednak oba obiekty posiadają wiele cech pozwalających na stwierdzenie, iż reprezentują wspólny kierunek w architekturze. Do cech tych należą:

- forma złożona, którą trudno odebrać bez doświadczenia przebywania w niej 
- nawiązanie do starej architektury z wytworzeniem nowych form, ale tak ukształtowanych, iż duża część odbiorców może uznać obiekt za pochodzący z dawnych wieków

- kształtowanie fasad w sposób złożony z wyraźnym wyodrębnieniem części składowych budynku i nadaniem ważnej roli otworom i ich obramieniom

- ukształtowanie obiektu nie jako jednolitej bryły, lecz złożonego układu przestrzeni i elementów w sposób czyniący z obiektu rodzaj miniaturowego założenia urbanistycznego

- wykończenie powierzchni masywnymi materiałami wykończeniowymi stanowiącymi integralną część jego konstrukcji

- włączenie zastosowanych rozwiązań konstrukcyjnych do kształtowania zewnętrznego wyrazu architektury obiektu

W zastosowany w artykule sposób można tworzyć kolejne kierunki. Można także znaleźć więcej przykładów architektury odpowiadającej zarysowanym tu dwóm kierunkom. Oczywiście im więcej przykładów będziemy chcieli znaleźć tym trudniej będzie nam znaleźć takie które będą posiadały wszystkie wymienione cechy. Jednakże brak spełnienia którejś z cech nie musi od razu wykluczać mieszczenia się w kierunku. Bowiem poszczególne dzieła mogą być przykładami określonego kierunku w jego mniej lub bardziej czystej postaci.

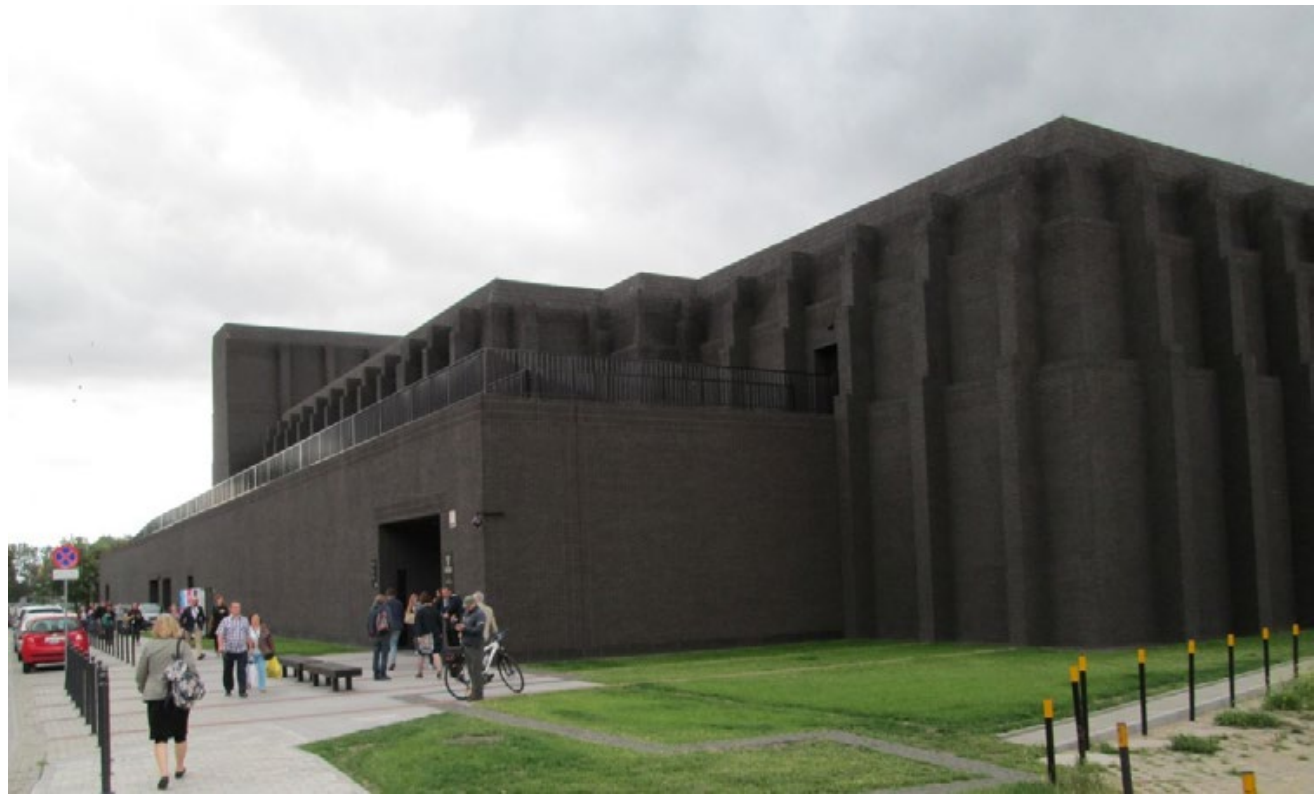

Ryc. 5. Gdański Teatr Szekspirowski. Widok z zewnątrz z północnego zachodu. Źródło: fot. H. Trammer, 26 lipca 2015 r.

Fig. 5. Gdansk Shakespeare Theatre. View from outside from the northwest side. Source: phot. Hubert Trammer, July $26^{\text {th }}, 2015$ 

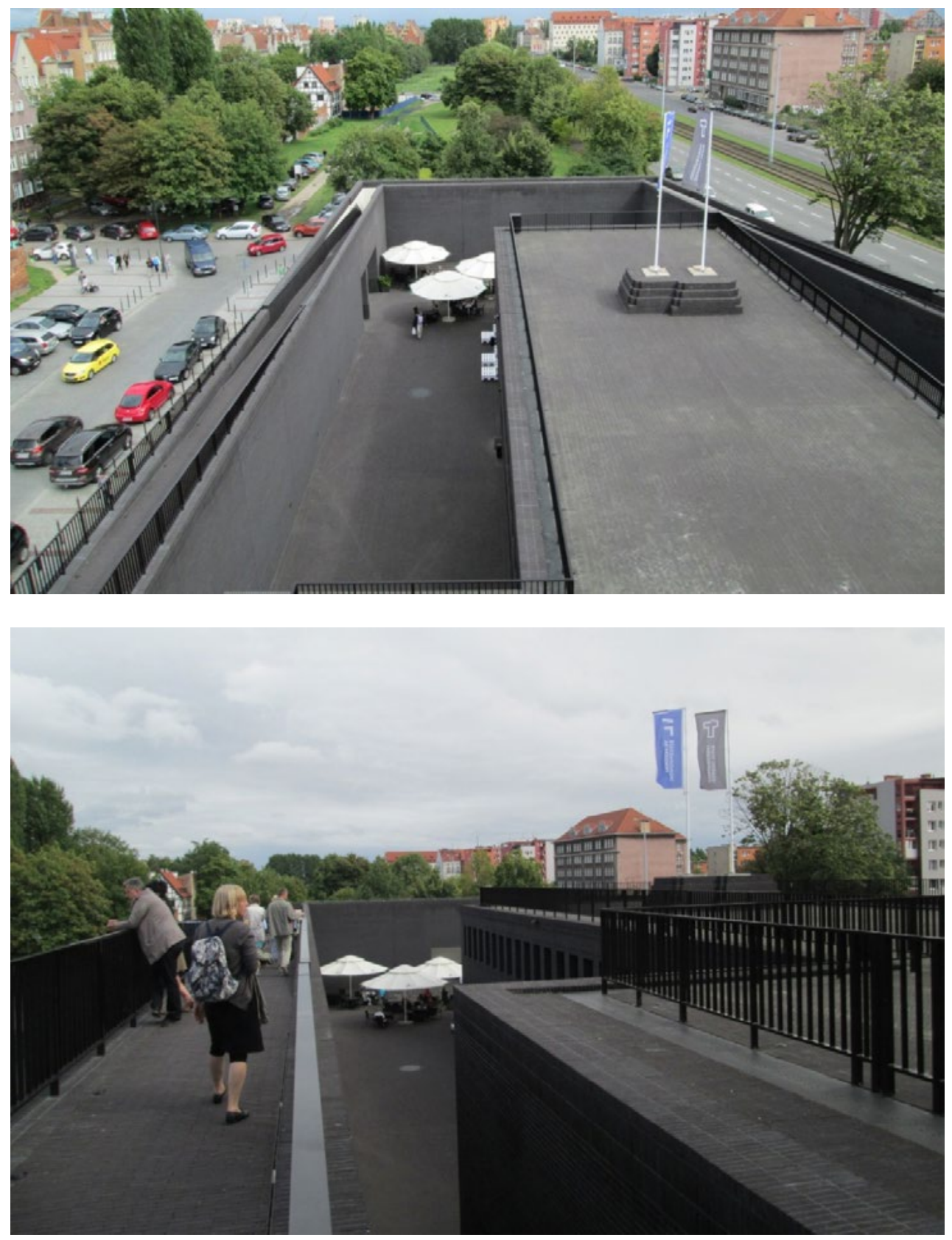

Ryc. 6. i 7. Gdański Teatr Szekspirowski. Widok z góry na część spośród dziedzińców obiektu. Źródło: fot. H. Trammer, 26 lipca 2015 r.

Fig. 6. \& 7. Gdansk Shakespeare Theatre. View from the top to some of the courtyards of the building. Source: phot. Hubert Trammer, July $26^{\text {th }}, 2015$ 


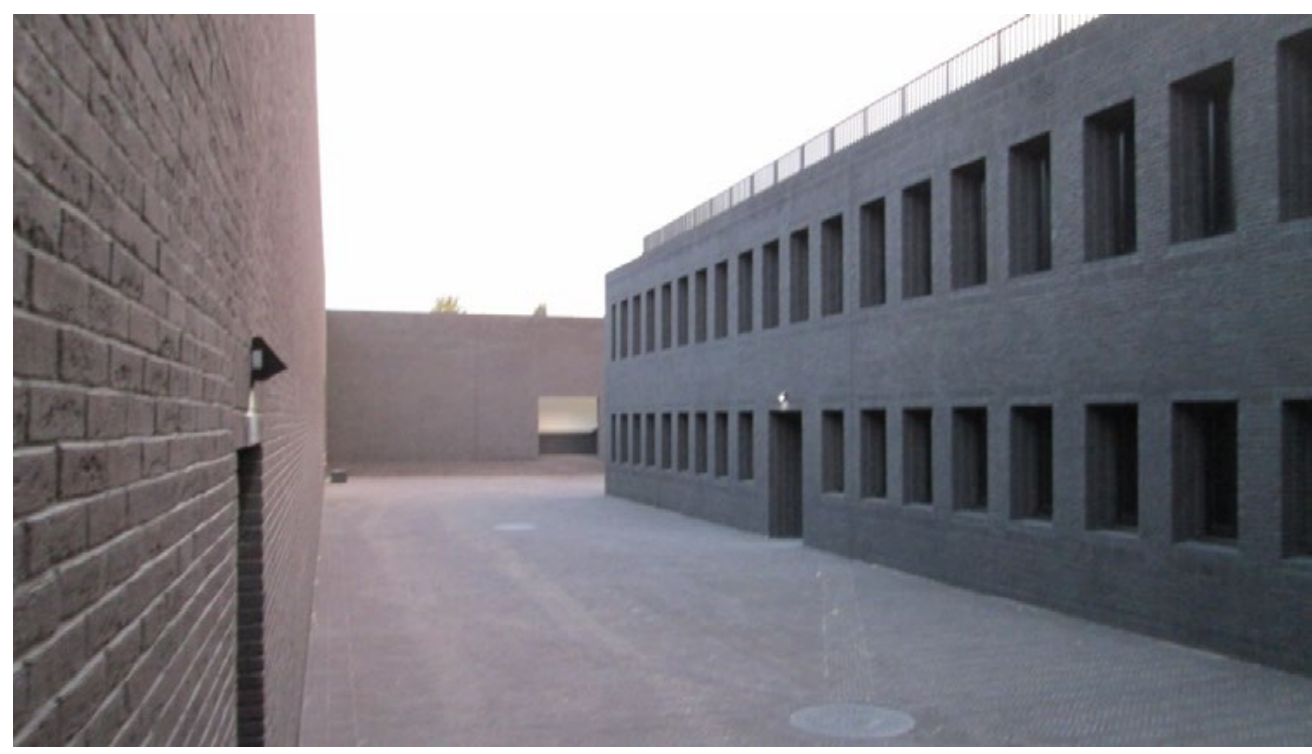

Ryc. 8. Gdański Teatr Szekspirowski. Widok wewnątrz jednego z dziedzińców. Źródło: fot. H. Trammer, 1 października 2014 r.

Fig.8. Gdansk Shakespeare Theatre. Detail of the elevation insi de the courtyard with window flaming. Source: phot. Hubert Trammer, October $1^{\text {st }}, 2014$

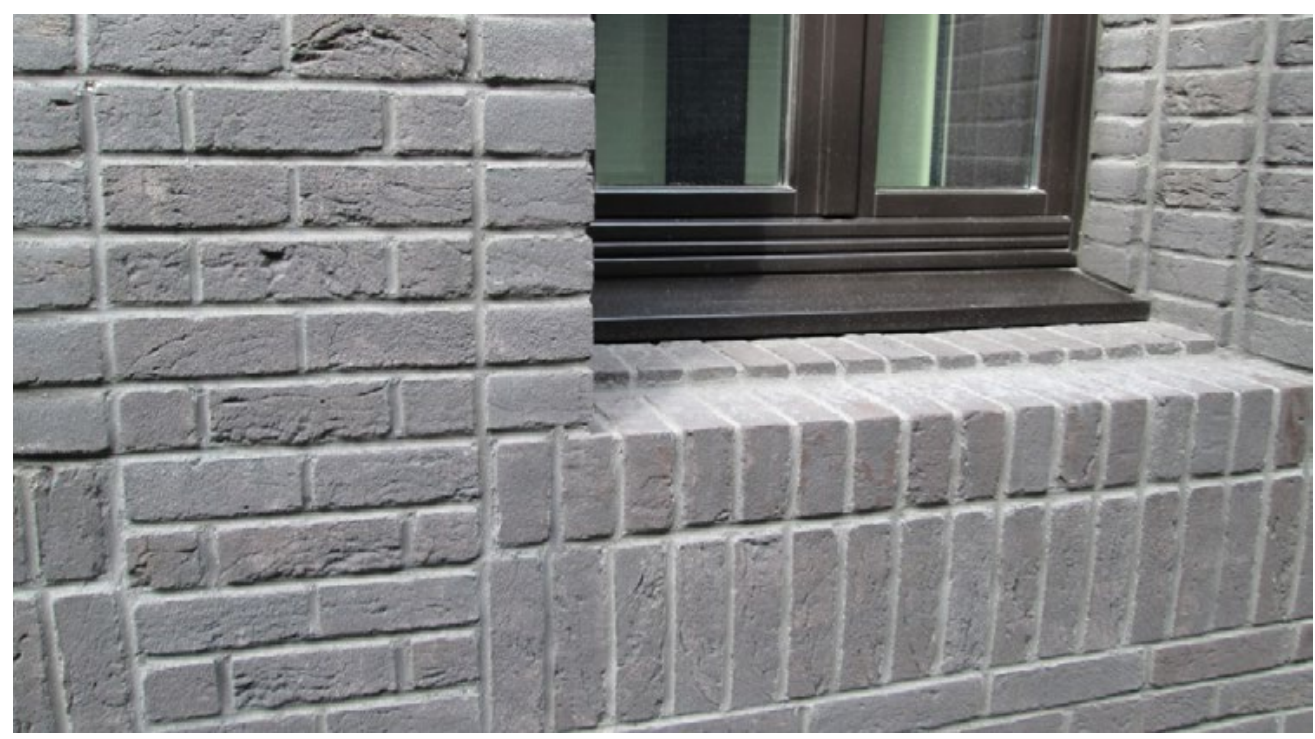

Ryc. 9. Gdański Teatr Szekspirowski. Detal elewacji wewnątrz dziedzińca z obramieniem okna. Źródło: fot. H. Trammer, 26 lipca 2015 r.

Fig. 9. Gdansk Shakespeare Theatre. Detail of the elevation insi de the courtyard with window flaming. Source: phot. Hubert Trammer, July $26^{\text {th }}, 2015$ 


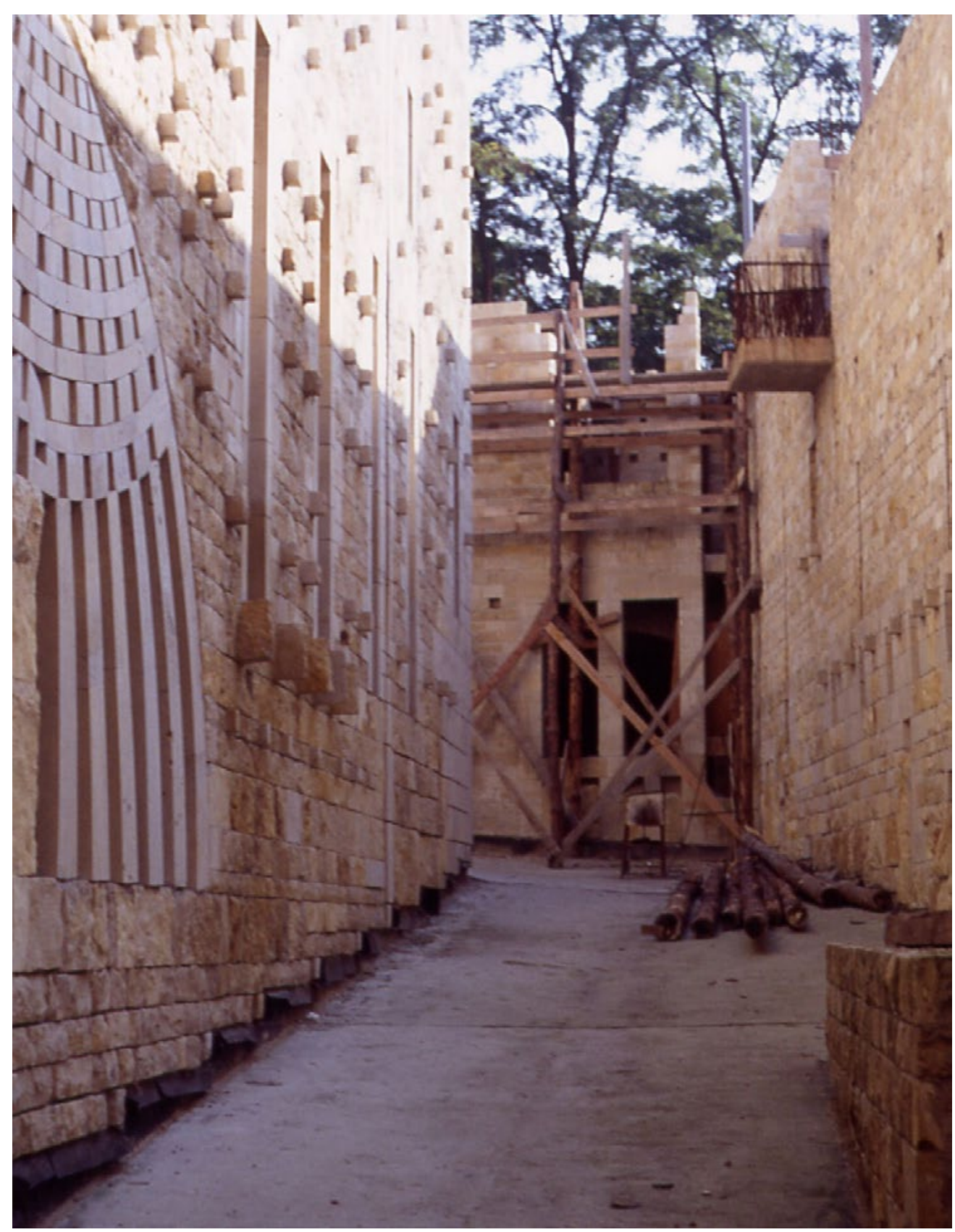

Ryc. 10. Klasztor Franciszkanów w Tychach. Przypominająca uliczkę średniowiecznego miasta przestrzeń na terenie klasztoru. Źródło: fot. H. Trammer, wrzesień $2005 \mathrm{r}$.

Fig. 10. Franciscn Monastery in Tychy. The space insi de the monatery which looks simararly to the lane of the medieval town. Source: phot. Hubert Trammer, September , 2005 

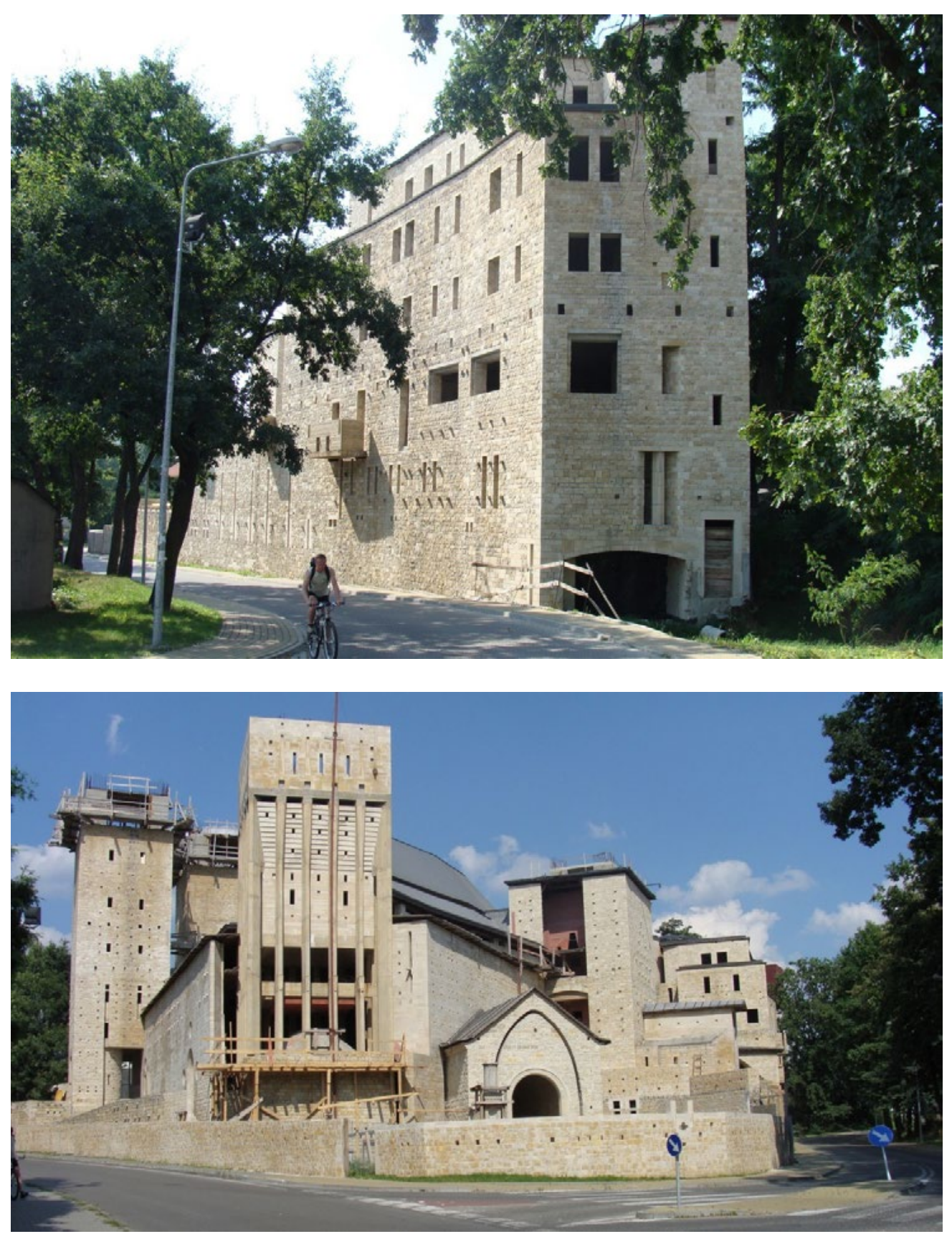

Ryc. 11. i 12. Klasztor Franciszkanów w Tychach. Widoki z przestrzeni przylegających ulic. Źródło: fot. H. Trammer, 1 sierpnia 2009 r.

Fig. 11. \& 12. Franciscan Monastery in Tychy. View from the space of the surrounding street. Source: phot. Hubert Trammer, August 1 $1^{\text {st }}, 2009$ 


\title{
PIŚMIENNICTWO
}

Boguszewicz P., Jabłoński A., Mikulski A., 2002, Stanisław Niemczyk. Krajobraz pierwotny (wywiad ze Stanisławem Niemczykiem), Architektura \& Biznes, 12/2002.

Deńko S., 2014, Kontynuacja wizji Tadeusza Kantora, Architektura-murator, 10/2014.

Niemczyk S., 2008, Kościót i klasztor św. Franciszka i św. Klary w Tychach, Archivolta, 2 (38)/ 2008.

Skolimowska A., 2015, Nagroda Unii Europejskiej dla Filharmonii, Architektura-murator, 7/2015.

Żylski T.,2014, Historia teatru, Architektura-murator, 11/2014.

\section{FOUR EXAMPLES WHICH REPRESENT TWO DIRECTIONS GLIMPSES OF POLISH ARCHITECTURE OF THE $21^{\text {ST }}$ CENTURY}

\begin{abstract}
This publication presents four works of architecture built in Poland in the 21st century. The four works are grouped in two pairs composed on the base of groups of characteristics which can be regarded as creating together the directions of architecture. Main subject of publication is supplemented by preliminary considerations on possible fields of analysis of architecture built in Poland in the 21st century.
\end{abstract}

Keywords: polish architecture, Architecture of the 21st century, contemporary architecture, Szczecin Philharmonic, Cricoteka, Gdansk Shakespeare Theathre, architektura polska, architektura XXI wieku, architektura współczesna, Filharmonia Szczecińska, Cricoteka, Gdański Teatr Szekspirowski, Klasztor Franciszkanów w Tychach, Estudio Barozzi Veiga, Renato Rizzi, Stanisław Niemczyk 